УДК 621.9 .031

DOI: $10.18372 / 0370-2197.3(88) .14922$

Р. М. ДЖУС, М. Г. СТАДНІЧЕНКО ${ }^{I}$, С. А. ПЛЕШКУНОВ ${ }^{l}$, Ю. О. ГРАДИСЬКИЙ

${ }^{1}$ Харківський національний університет Повітряних Сил імені Івана Кожседуба, Украӥна

${ }^{2}$ Харківський національний технічний університет сільського господарства

ім. П.Василенка, Украӥна

\title{
ПОРІВНЯЛЬНИЙ АНАЛІЗ ПАРАМЕТРІВ ЗНОСОСТІЙКОСТІ ЗРАЗКІВ, ЗМЩЦЕНИХ ЦЕМЕНТУВАННЯМ ТА ІОННО-ПЛАЗМОВИМ АЗОТУВАННЯМ, ПРАЦЮЮЧИХ В УМОВАХ БАГАТОЦИКЛОВОГО ЗНОШУВАННЯ
}

\begin{abstract}
Проведено порівняльні випробування зразків, моделюючих роботу шестерень вузла, що качає, авіаційних аксіально-поршневих насосів, зміцнених традиційним методом цементаиії та новим, більш досконалим методом зміцнення іонно-плазмовим азотуванням за технологією «AVINIT N», яка розроблена на Харківському агрегатобудівному підприємстві АТ «ФЕД». Визначено значні переваги нової технології.
\end{abstract}

Ключові слова: «AVINIT N», Авініт H, багаточиклове зношування, втомне зношування, іонно-плазмове азотування, порівняльні випробування на зносостійкість, иементаиія.

Вступ та постановка проблеми. В промисловості вихід з ладу механізмів у переважній більшості випадків виникає внаслідок механічного зношування [1] деталей машин. Якщо виключити найгрубіші форми зношування, обумовлені мікрорізанням і схоплюванням поверхонь, які зазвичай не спостерігаються при нормальній роботі вузла тертя, найбільш загальною формою пошкоджуваності при терті є втома, що протікає під дією високих знакозмінних і циклічних пружнопластичних навантажень, які сприймаються локальними ділянками поверхонь на тлі теплових, хімічних, адгезійних та інших контактних взаємодій поверхні 3 контртілом і середовищем. Тому найбільш важливим і одночасно важкоконтрольованим є втомне зношування [2]. Цьому виду зношування присвячено більшу частину теоретичних та експериментальних досліджень, наприклад при проектуванні агрегатів авіаційної паливної автоматики(аксіально-поршневих насосів).

Висока вартість виготовлення та ремонту цих агрегатів, а також їх невеликий ресурс, обумовлюють загальну високу ціну цієї галузі авіаційної промисловості. У зв'язку з цим у сучасному авіаційному агрегатобудуванні проводяться роботи по створенню насосів-регуляторів паливної автоматики шестеренного типу, які є дешевшими у виготовленні і ремонті та менш вимогливі до якості палива. Так, на Харківському агрегатобудівному підприємстві АТ «ФЕД» розроблено дослідний зразок такого насосу (рис. 1, a). 3 метою підвищення ресурсних показників у даний час виконуються дослідно-конструкторські роботи з підвищення ресурсних показників основних трибосистем, які відповідають за його ресурс (шестерні вузла, що качає (рис. 1, б)). 3 цією метою було запропоновано замінити традиційний метод зміцнення їх робочих поверхонь цементуванням на більш досконалий метод зміцнення іонно-плазмове азотування «AVINIT N», розроблене на АТ «ФЕД» [3].

Використання іонно-плазмових технологій азотування замість цементації 3 метою підвищення контактної втомної міцності поверхонь деталей обумовлено такими перевагами цієї технології, як збереження розмірів та висока чистота обробки поверхонь, внаслідок чого відпадає необхідність їх механічного доопрацювання після зміцнення $[4,5]$. 


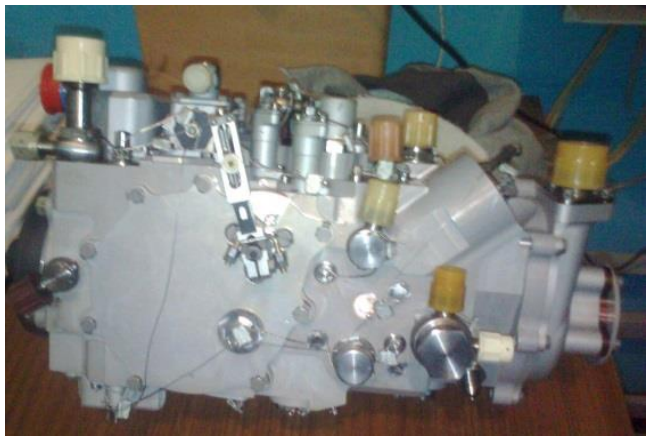

$a$

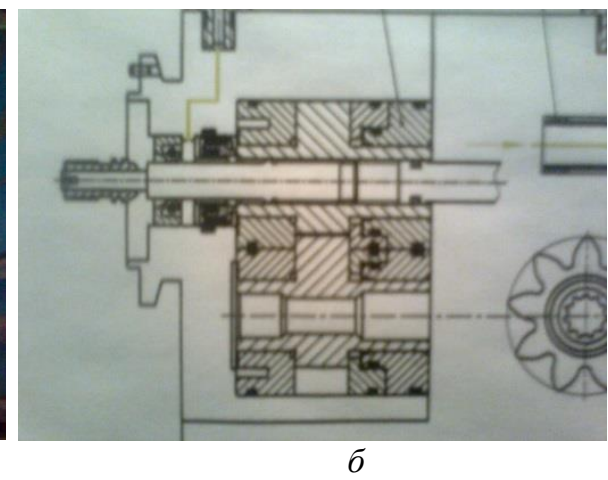

$\sigma$

Рис. 1. Паливний насос-регулятор шестеренного типу НР-3000: $a$ - загальний вигляд; $\sigma$ - схема вузла, що качає

Аналіз останніх досліджень і публікацій. Для прийняття рішення про можливість застосування такої заміни методу зміцнення виникла необхідність у проведенні комплексних досліджень на втому.

Втомний механізм пошкоджуваності поверхневого шару характеризується наявністю двох фаз: прихованого (латентного) періоду, протягом якого видиме руйнування матеріалу відсутнє при поступовому накопиченні дефектів, і фази швидкого руйнування, коли при досягненні певної концентрації мікропошкодження «втомлений» матеріал диспергується у вигляді частинок зносу $[6,7]$. Втомний знос найбільш характерний при терті кочення в кулькових і роликових підшипниках, опорно-поворотних пристроях, ковзанках, що обертаються бандажах і т. д., а також при терті ковзання в механічних вузлах, що здійснюють зворотно-поступальні рухи. Знос матеріалів має втомну природу і може мати малоцикловий (при пластичних деформаціях) і багатоцикловий (при пружних деформаціях) характер [2].

Перші пояснення втоми пов'язували з наявністю при терті високочастотних пружних знакозмінних навантажень, що виникають в матеріалі поверхневого шару внаслідок періодичного зачеплення і розчеплення виступів шорсткостей контактуючих поверхонь, а частота контактування виступів знаходиться в межах 105...107 Гц [8]. При цьому вважалося, що пластичний контакт має місце тільки при припрацюванні поверхонь, а після багаторазових циклів деформації взаємодія поверхонь стає переважно пружною [9]. На відміну від цієї точки зору, Чаллен показав, що пластичні деформації відіграють основну роль в процесі утворення частинок зносу навіть після припрацюванні поверхонь [10]. При цьому руйнування поверхневого шару є результат малоцикловой втоми і число циклів деформування поверхні може визначатися 3 рівняння Менсона-Коффина [11]. Недавні дослідження з використанням хвильової моделі контакту привели до аналогічного висновку $[12,13]$. Однак питання про механізм втомного руйнування до теперішнього часу перебуває на стадії розвитку, що підтверджується пошуками критерію втомного руйнування і висуванням нових гіпотез. Зокрема, А. Елеод визначив, що відділення частинок зносу може бути викликано трьома факторами: зниженням роботи руйнування матеріалу поверхневого шару до нульового значення під впливом різних факторів в полі пружних напружень; накопиченням пошкоджень в умовах пружних напружень; вичерпанням ресурсу пластичності в області пластичного контакту [14]. 
Всі три процеси мають загальний характер, згідно з яким руйнування настає при вичерпанні локального ресурсу пластичності. 3 теоретичних досліджень В.Федорова, в процесі контактної взаємодії одночасно проходять два процеси: накопичення внутрішньої енергії та іï дисипація [15]. Причому, дисипативна складова $\epsilon$ визначним фактором, який обумовлений структурою поверхневого шару. У відповідність 3 цим, авторами було запропоновано оцінювати втомну міцність питомою енергією дисипації за один цикл навантаження $\bar{E}_{\text {дис }}$ [16]. Для трибосистеми (ТС) з азотуванням цей параметр $\bar{E}_{\text {дисА }}$ у порівнянні з ТС з цементацією буде мати вигляд:

$$
\bar{E}_{\text {дисА }}=\frac{E_{\text {підвА }}-E_{\text {підвЦ }}}{n_{\text {цА }}},
$$

де $E_{\text {підвА }}, E_{\text {підвц }}$ - вся енергія, що підведена до трибосистем (з азотуванням та цементацією відповідно) при їх роботі до руйнування за параметром акустичної емісії (АЕ) [17];

$n_{\text {цА }}$ - кількість циклів до початку втомного руйнування ТС $з$ азотуванням.

За допомогою цього параметру можна проводити порівняння різних конструкційних матеріалів та методів їх зміцнення (для вибору більш ефективних) при проведенні прискорених випробувань на втомну міцність.

Виходячи з викладеного, саме умови роботи трибоспряження (величина діючих навантажень) визначають, за яким механізмом відбувається основна частина зношування - малоциклове чи багатоциклове. За високих навантажень такий поділ можна зробити тільки умовно. Це було враховано авторами у подальших експериментальних дослідженнях.

Метою даної роботи є порівняльна оцінка параметрів зносостійкості досліджуваних трибосистем саме від малоциклового зносу.

Основний матеріал дослідження. Зміцнююче азотування «AVINIT N» розроблено в АТ «ФЕД» як енерго- та ресурсозберігаючу технологію. Окрім того, процес вакуумного іонно-плазмового «легування», використаний в технології «AVINIT N», характеризується підвищеною екологічністю, що разом 3 енергозбереженням зумовлює перспективність іiі подальшого розвитку. Регулюванням структури, фазового складу і товщини зміцненого шару досягається підвищення зносостійкості та антифрикційних властивостей ТС.

Широке використання даної технології в агрегатобудуванні можливе після проведення випробувань на порівняння 3 традиційною технологією цементування для досягнення визначеної мети роботи.

Умови проведення експериментальних досліджень, матеріали, лабораторне обладнання та методи досліджень докладно викладено у роботах $[16,18,19]$. Робота проводилась 3 метою порівняння трибологічних характеристик конструкційних матеріалів, які моделюють роботу зубчатих зчеплень, зміцнених за традиційною технологією цементуванням та перспективною технологією іонноплазмового азотування «AVINIT N» AT «ФЕД».

Експерименти, проведені на контактну втому при великих навантаженнях $\left(\sigma_{\max } \approx 1400 \mathrm{MПа,} \mathrm{(розрахована} \mathrm{за} \mathrm{формулою} \mathrm{Герца)} \mathrm{багатоциклове} \mathrm{втомне} \mathrm{зно-}\right.$ шування) показали багатократну перевагу цього методу зміцнення поверхонь за параметром сумарного зносу (біля 10 разів) [18]. 
Однак, при даних умовах випробувань неможливо відрізнити знос малоциклової втоми (який відбувається за механізмом утворення та руйнування на поверхнях тертя вторинних структур) від багатоциклової втоми (при якому дефекти накопичуються у великих об'ємах поверхневого шару). Тому цілком актуальним $\epsilon$ завдання проведення таких експериментальних випробувань для оцінки параметрів зносостійкості саме від малоциклової втоми. Для цього величина питомого навантаження в зоні контакту в експериментальних дослідженнях була знижена (у порівнянні з експериментами, проведеними у попередніх роботах [16, 18]) до $\sigma_{\max } \approx 500 \mathrm{MПа} \mathrm{(за} \mathrm{формулою} \mathrm{Герца).}$

Решта умов та параметрів випробувань відповідали випробуванням на зносостійкість за механізмом багатоциклової втомної міцності [18].

Об'єктами випробовувань були зразки, зміцнені за технологією «AVINIT N», у вигляді «дисків» діаметром 50 мм і висотою 12 мм. Для порівняння випробували зразки того же матеріалу, зміцнені цементуванням по серійній технології АТ «ФЕД. Випробували зразки 3 одного матеріалу - сталь 20ХЗМВФ ГОСТ 20072-74. Марка матеріалу обрана з умови, що дана сталь може зміцнюватися як цементацією, так і азотуванням

Випробування проведено на машині третя 2070 СМТ-1 впродовж 8 годин в умовах тертя кочення 3 проковзуванням 20\% зі швидкістю обертання нижнього зразка (ведучого) 500 об/хв. Схема випробувань - «диск-диск». Змащування здійснювали маслом М-8В ГОСТ 10541 шляхом занурення в нього нижнього «диску». Навантаження при випробуваннях складало $1500 \mathrm{H}$.

Триботехнічні характеристики оцінювались по показникам вагового зносу, коефіцієнта тертя і середньоповерхневої температури випробуваних зразків. Відсутність початкових пошкоджень втомного характеру оцінювалися за показниками AЕ [17, 20-22]. Встановлено, що перехід від нормального зношування до початкових пошкоджень втомного характеру супроводжується сигналами акустичної емісії, енергоємність яких вище від першопочаткового рівня в $5 \ldots 10$ разів, рис. 2 [17].

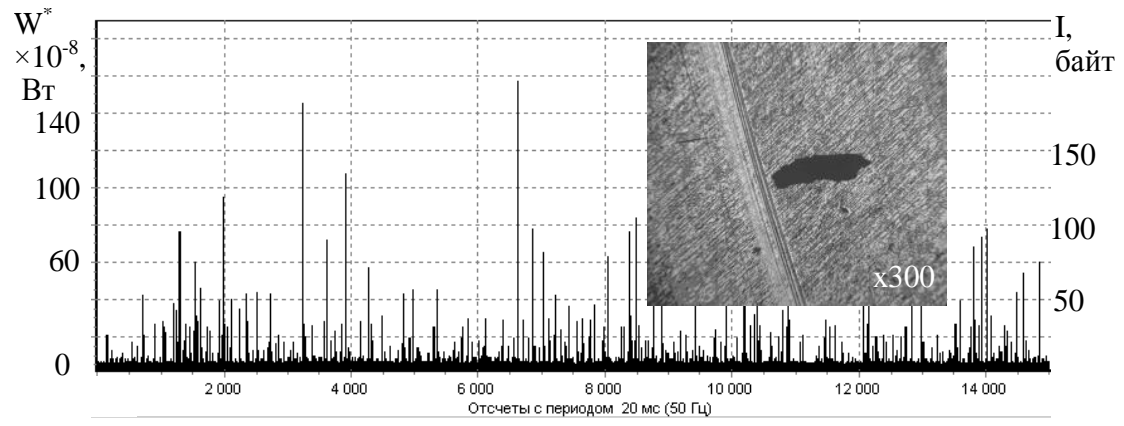

Рис. 2. Діаграма зміни швидкості зношування при переході до втомного пошкодження

Метод акустичної емісії є надзвичайно ефективним інструментом контролю швидкості зношування в реальному масштабі часу і використовувався для порівняння цього параметру на етапі припрацювання, а також на сталих режимах роботи ТС.

Вигляд інформаційно-діагностичної системи (ІДС) для прийому та обробки сигналів АЕ наведено на рис. 3 [16]. 


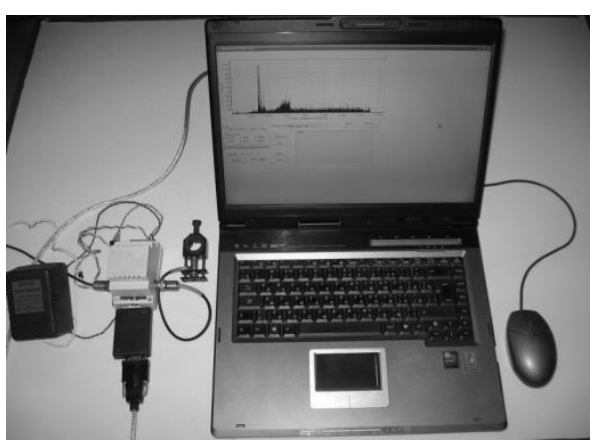

Рис. 3. Інформаційно-діагностична система для прийому та обробки сигналів акустичної емісії

Під час випробувань фіксували момент тертя, який перерахували в коефіцієнт тертя $\left(f_{\text {mер }}\right)$ за формулою: $f_{\text {mер }}=2 M / p d$, де $p$ - навантаження; $d$ - діаметр «диска».

Середньоповерхнева температура зразків вимірювалась пірометром Німбус-760.

Дана ІДС дозволяє реєструвати швидкість зношування за час 20 мсек у відносних інформаційних одиницях швидкості зношування. Таким чином, зношування реєструється 3 моменту відділення перших часток зносу 3 поверхні тертя в реальному масштабі часу за весь період випробувань.

Металофізичні дослідження мікрорельєфу поверхні тертя проводились до та після проведення випробувань. Величину вагового зносу за весь термін випробування впродовж 8 годин визначали на аналітичних лабораторних вагах ВЛА2003 точністю $1 \times 10^{-4}$ г.

Результати випробувань представлені табличним методом, в яких відображені середньо арифметичні значення параметрів, що вимірюються за кожною групою однойменних зразків (по 5 пар зразків для кожного з видів зміцнення).

Результати триботехнічних випробувань. Результати аналізу акустикоемісійного випромінювання за весь період випробувань показав, що параметрами акустичної емісії чітко реєструється період навантаження, припрацювання та усталеної роботи трибосистем. Однак при роботі трибосистеми з азотуванням припрацювання відбувається зі збільшеною швидкістю зношування, що скоріш обумовлено станом поверхні тертя (шорсткості) (рис. 4).

Для трибосистем $з$ цементацією припрацювання має менш виражений характер, що також обумовлено станом поверхні тертя (полірування). Діаграми зміни параметра акустичної емісії для всіх трибосистем, що досліджуються, представлені на трьох ділянках (на початку випробувань, середина випробувань, кінець випробувань), рис. 5.

Різниця у здатності до припрацювання досліджуваних зразків пояснюється різницею вихідної шорсткості зразків з різними видами зміцнення (рис. 6). Для всіх досліджуваних трибосистем сигнали акустичної емісії, які можна було б віднести до втомного багатоциклового пошкодження - не виявлено.

Результати визначення тріботехнічних параметрів досліджуваних трибосистем на початку та в кінці випробувань представлені в табл. 1.

Аналіз результатів випробувань на зносостійкість підтвердив їх гарну сходимість 3 результатами, отриманими на основі аналізу акустично-емісійного випромінювання трибосистем. Величини зносів пар тертя, зміцнених за технологі$\epsilon ю$ «AVINIT N» вирівнюються та мають близькі показники, що підтверджує дані, одержані при аналізі акустичного випромінювання під час випробувань. 

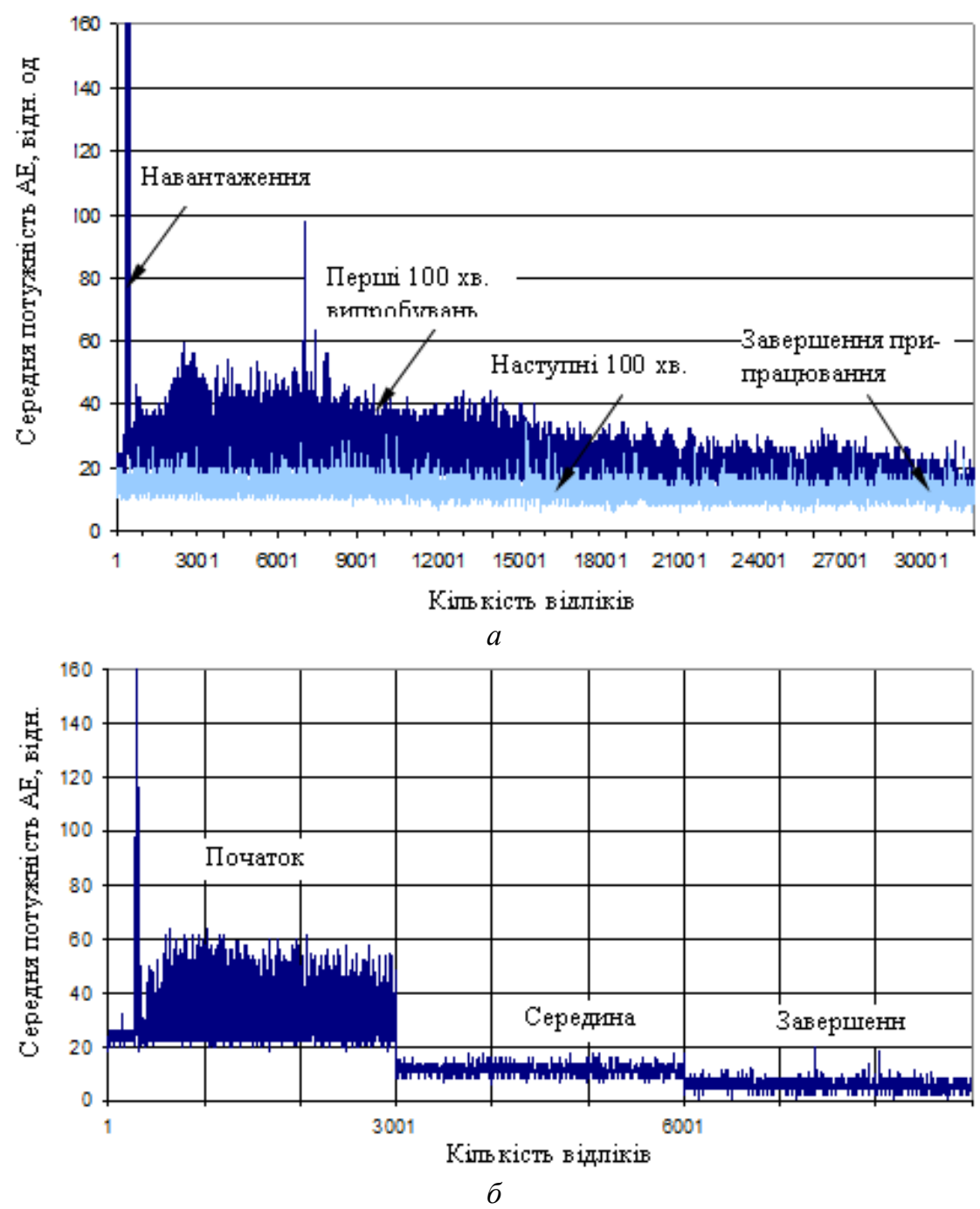

Рис. 4. Діаграма зміни параметра усередненої потужності акустичної емісії (азотування): $a$ - на етапі припрацювання, $\sigma$ - за періодами випробувань

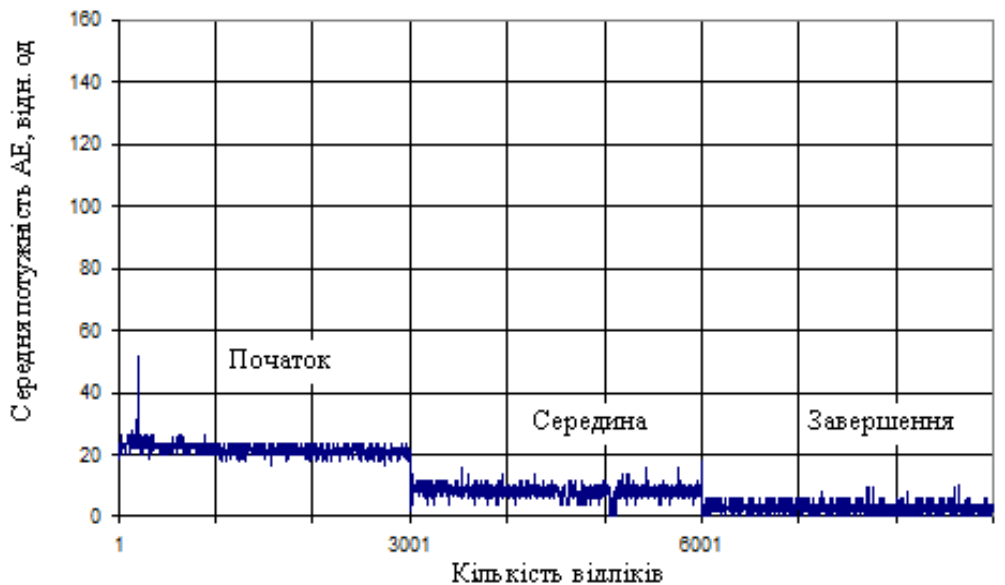

Рис. 5. Діаграма зміни параметра усередненої потужності акустичної емісії (цементація) 

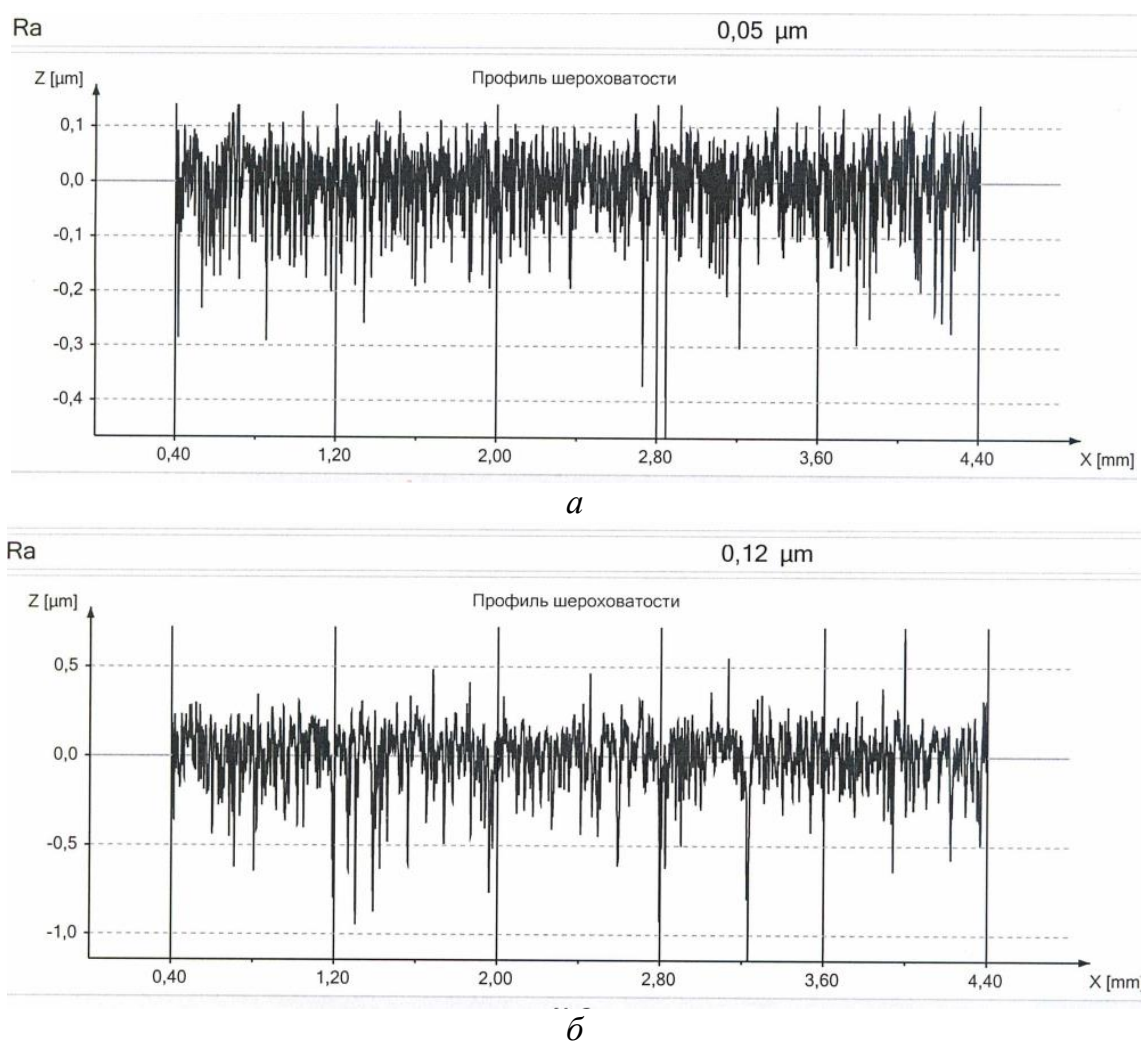

Рис. 6. Профіль шорсткості зразків, до випробувань: $a$ - зміцнених цементацією; $\sigma$ - зміцнених азотуванням

Таблиия 1

Результати визначення триботехнічних параметрів

\begin{tabular}{|c|c|c|c|c|c|}
\hline \multirow{2}{*}{$\begin{array}{l}\text { Зміцнення } \\
\text { зразків }\end{array}$} & \multicolumn{2}{|c|}{$\begin{array}{c}\text { Коефіцієнт тертя / середньоповерхнева } \\
\text { температура, }{ }^{\circ} \mathrm{C} \\
\end{array}$} & \multicolumn{2}{|c|}{ Ваговий знос зразків, г } & \multirow{2}{*}{$\begin{array}{c}\text { Загальний } \\
\text { знос }\end{array}$} \\
\hline & $\begin{array}{c}\text { На початку випробу- } \\
\text { вань }\end{array}$ & $\begin{array}{l}\text { В кінці випро- } \\
\text { бувань }\end{array}$ & Ведучого & Веденого & \\
\hline Цементація & $0,108 / 59$ & $0,099 / 58$ & 0,0004 & 0,0007 & 0,0011 \\
\hline «AVINIT N» & $0,080 / 56$ & $0,069 / 44$ & 0,0010 & 0,0004 & 0,0014 \\
\hline
\end{tabular}

Початкові пошкодження втомного характеру на всіх парах, що досліджуються, не виявлено.

На заключному етапі роботи ТС коефіцієнти тертя для пар, зміцнених азотуванням, на 30\% нижче за зразки, зміцнені цементацією. Шорсткість зразків після випробувань практично вирівнюється (рис. 7). Тому зниження коефіцієнту тертя для азотування можна пояснити зміною фізико-механічних властивостей поверхневого шару.

\section{Висновки.}

1. Випробування на зносостійкість досліджуваних трибосистем показали, що втомне багатоциклове зношування (пітинг) за 8 годин випробувань на всіх досліджуваних парах тертя за показниками акустичної емісії не виявляється. Це обумовлено правильним підбором рівня контактних навантажень для матеріалів, які мають високі протипітингові властивості (цементація і азотування). 

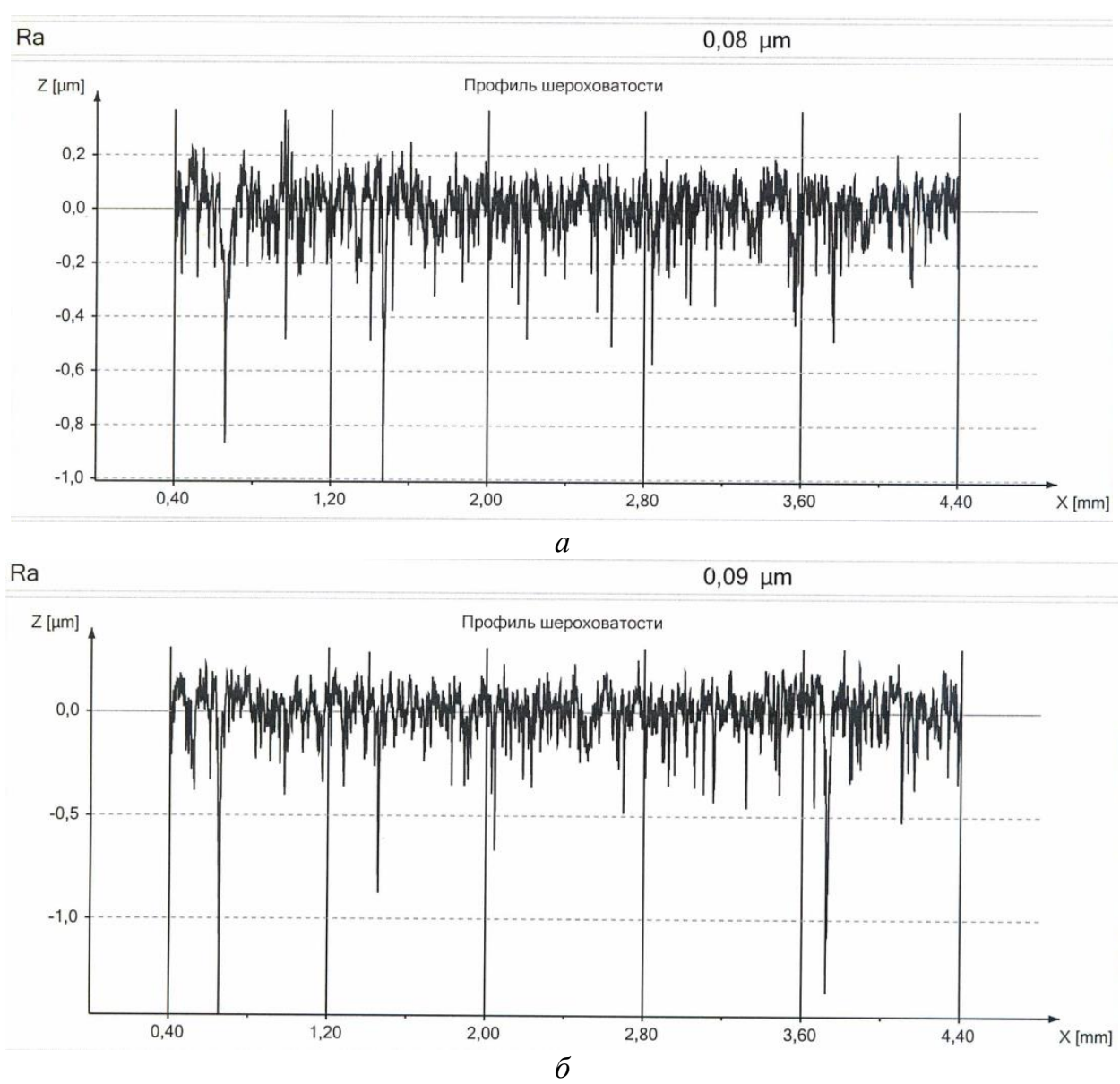

Рис. 7. Профіль шорсткості зразків, після випробувань: $a$-зміцнених цементацією; $\sigma$ - зміцнених азотуванням

2. Аналіз діаграми зміни акустичної емісії показали, що трибосистема з азотуванням протягом 100 хвилин роботи при коченні з 20\% проковзуванням показує значну швидкість зношування на першому етапі (припрацювання), що зумовлено станом поверхневого шару, його значної шорсткості.

3. Трибосистема з цементацією при тих же умовах випробувань не має чітко визначеного за часом припрацювання. Швидкість зношування плавно зменшується за весь період зношування (8 год.).

4. За показниками акустичної емісії зносостійкість досліджуваних трибосистем при восьми годинах випробувань розрізняються незначно і розподіляються наступним чином: цементовані зразки - рівень акустичної емісії 4...5 відн. од.; азотовані зразки - рівень акустичної емісії 5...7 відн. од.

5. Аналіз результатів визначення коефіцієнтів тертя свідчить про те, що коефіцієнти тертя зразків, зміцнених за технологією «AVINIT N» суттєво, приблизно на 30\% менші, ніж коефіцієнти тертя, одержані при випробуваннях зразків зміцнених цементацією.

6. Величина зносу зразків, зміцнених за технологією «AVINIT N» значно перевищує знос цементованих зразків на початку випробувань, але в кінці випробувань різниця в величинах зносу зразків зміцнених за технологією «AVINIT N» та цементацією нівелюється. 


\section{Список літератури}

1. Xie, Y. and Williams, J.A. The Generation of Worn Surfaces By the Repeated Interaction of Parralel Grooves, Wear, 1993, pp. 864-872.

2. Ибатуллин И. Д. Кинетика усталостной повреждаемости и разрушения поверхностных слоев: монография. Самара : Самар. гос. техн. ун-т, 2008. 387 с.

3. Sagalovich V.V., Sagalovich, A.V. The method of ion-plasma precision nitriding of the surfaces of metal products, Patent 2555692, Russian Federation, C23C8/36 (H01J 37/00), C23C14/48, stated 27.12.2014; publ. 10.07.2015, Bull. No. 19, 13 p.

4. Могильная Е. П., Дубасов В. М. Ионное азотирование изделий из конструкционной стали 38ХМФА. Ресурсозберігаючі технології виробництва та обробки тиском матеріалів у машинобудуванні. 2013. №1. С. 193-198.

5. Костик К. О. Костик В. О. Порівняльний аналіз впливу газового та іонноплазмового азотування на зміну структури і властивості легованої сталі 30Х3ВА. Вісник Нац. техн. ун-ту «ХПІ»: зб. наук. пр. Темат. вип. : Нові рішення в сучасних технологіях. Харків : НТУ «ХПІ». 2014. №48 (1090). С. 21-41.

6. Громаковский Д. Г. Система понятий и структура моделей изнашивания. Трение и износ. 1997. Том 18. №1. С. 53-62.

7. Осипов, К. А. Некоторые активируемые процессы в металлах и сплавах. М. : АН CCCP, 1962. $131 \mathrm{c}$.

8. Шведков Е. Л., Ровинский Д. Я., Зозуля В. Д., Браун Э. Д. Словарь-справочник по трению, износу и смазке деталей машин: Справочник. Киев : Наукова думка, 1979. 188 с.

9. Крагельский И. В. Добычин М. Н., Комбалов В. С. Основы расчетов на трение и износ. М. : Машиностроение, 1977. 526 с.

10. Challen, J.M., Kopalinsky, E.M. and Oxley, P.L.B. An asperity deformation model for relating the coefficient of friction and wear in sliding metal friction, in Tribology - Friction, Lubrication and Wear fifty years on, Vol II, I MechE., London (1987) Paper C156/87.

11. Терентьев В. Ф., Петухов А. Н. Усталость высокопрочных металлических материалов. М.: Машиностроение, 1981. 240 с.

12. Dowson D. Progress in Tribology: a Historical Perspective. Plenary Papers of The World Tribology Congress. Bookcraft Limited. Bath. UK. 1997. 300. P. 3-20.

13. Gromakovsky D. G., Malyarov A. N., Samarin Y. P. Modelling and Wear Calculation on Friction. Absrtacts of Papers of the World Tribology Congress. Bookcraft Limited. Bath. UK. 1997. 462 p.

14. Eleod A. Numerical modelling of particle detachment. Absrtacts of Papers of The World Tribology Congress. Bookcraft Limited. Bath. UK. 1997. P. 44.

15. Федоров В. В. Кинетика повреждаемости и разрушения твердых тел. Ташкент : ФАН, 1985. $168 \mathrm{c}$.

16. Стадниченко В. М., Джус Р. М., Плешкунов С. А. Методика прискореної оцінки показників втомної пошкоджуваності конструкційних матеріалів. Системи озброєння і військова техніка. 2019. № 2 (58). C. 122-131. https://doi.org/10.30748/soivt.2019.58.15.

17. Стадниченко В. М., Стадниченко М. Г., Джус Р. М., Трошин О. М. Про границі застосування методу акустичної емісії при вирішенні задач трибо діагностики. Збірник наукових праць ХІ ВПС. 2004. №1 (10). С. 187-194.

18. Джус Р.М., Стадниченко М. Г., Попов В. В., Плешкунов С. А., Семенов Я. І. Порівняльна оцінка технологічних методів цементації та іонно-плазмового азотування при ïx використанні для зміцнення високонавантажених вузлів авіаційної техніки. Наука $\mathrm{i}$ техніка Повітряних Сил Збройних Сил України. 2020. № 2 (39). С. 54-61. https://doi.org/10.30748/nitps.2020.39.06.

19. Джус Р. М., Стадниченко М. Г., Стадниченко В. М., Попов В. В., Плешкунов С. А., Мікроструктурні та фазові особливості поверхневого шару, зміцненого іонноплазмовим азотуванням, як фактор підвищення втомної міцності. Збірник наукових праць Харківського національного університету Повітряних Сил. 2020. № 1 (63). C. 89-95. https://doi.org/10.30748/zhups.2020.63.12. 
20. Zaporozhets V. V., Stadnichenko V. M. Automated Systems for Tribodiagnostics of Contact Interactions. Journal of Friction and Wear. 2015. Vol. 36. № 3. P. 241-248.

21. Wang Zh., Wu X., Liu X., Cao Y., Xie J. Research on feature extraction algorithm of rolling bearing fatigue evolution stage based on acoustic emission. Mechanical Systems and Signal Processing. Vol. 113. 2018. P. 271-284.

22. Sause M., Hamstad M. Acoustic Emission Analysis. Comprehensive Composite Materials II. Vol. 7. 2018. P. 291-326.

Стаття надійшла до редакції 30.09.2020.

Джус Роман Миколайович - канд. техн. наук, старший науковий співробітник, старший викладач кафедри конструкції та міцності ЛА та двигунів Харківського національного університету Повітряних Сил імені Івана Кожедуба, dromnik1@gmail.com

Стадніченко Микола Григорович - канд. техн. наук, доцент, старший викладач кафедри аеродромно-технічного забезпечення Харківського національного університету Повітряних Сил імені Івана Кожедуба.

Плешкунов Сергій Анатолійович - старший викладач кафедри інженерноавіаційного забезпечення Харківського національного університету Повітряних Сил імені Івана Кожедуба.

Градиський Юрій Олександрович - канд. техн. наук, доцент, доцент кафедри ДТСЛК Харківського національного технічного університету сільського господарства імені Петра Василенка, gradiskiy@ khntusg.info 
R. M. DZHUS, M. G. STADNICHENKO, S. A. PLESHKUNOV, Y. O. GRADISKIY

\section{COMPARATIVE ANALYSIS OF WEAR RESISTANCE PARAMETERS OF SAMPLES, STRENGTHENED BY CEMENTATION AND ION-PLASMA NITROGENING, WHICH WORKING IN THE CONDITIONS OF MULTICYCLIC WEAR}

Comparative tests of samples simulating the operation of the gears of the pumping unit, aircraft axial-piston pumps, hardened by the traditional method of cementation and a new, more advanced method of hardening - ion-plasma nitriding technology "AVINIT N", developed at the Kharkiv aggregate-building enterprise JSC "FED". Tests for wear resistance of the studied tribosystems showed that fatigue multi-cycle wear (pitting) for 8 hours of testing on all studied friction pairs according to the indicators of acoustic emission is not detected. This is due to the correct selection of the level of contact loads for materials that have high anti-pitting properties (cementation and nitriding). Analysis of the diagram of the change in acoustic emission showed that the tribosystem with nitriding for 100 minutes of rolling with $20 \%$ slip shows a significant rate of wear in the first stage (running-in), due to the condition of the surface layer, its significant roughness. The tribosystem with cementation under the same test conditions does not have a clearly defined time of running-in. The wear rate gradually decreases over the entire wear period (8 hours). According to the indicators of acoustic emission, the wear resistance of the studied tribosystems at eight hours of testing differs slightly and is distributed as follows: cemented samples - the level of acoustic emission $4 . . .5$ relative units; nitrided samples - the level of acoustic emission 5...7 relative units. The analysis of the results of determining the coefficients of friction shows that the coefficients of friction of the samples, hardened by the technology "AVINIT N", are significantly about $30 \%$ lower than the coefficients of friction obtained by testing samples, strengthened by cementation. The amount of wear of samples, hardened by AVINIT N technology, significantly exceeds the wear of cemented samples at the beginning of the tests, but at the end of the tests the difference in wear values of samples hardened by AVINIT N technology and cementation is leveled.

Key words: AVINIT N, Авініт H, multicycle wear, fatigue wear, ion-plasma nitriding, comparative tests for wear resistance, cementation.

\section{References}

1. Xie, Y. and Williams, J.A. The Generation of Worn Surfaces By the Repeated Interaction of Parralel Grooves, Wear, 1993, pp. 864-872.

2. Ibatullin I. D. Kinetika ustalostnoj povrezhdaemosti i razrushenija poverhno-stnyh sloev: monografija. Samara : Samar. gos. tehn. un-t, 2008. 387 s.

3. Sagalovich V.V., Sagalovich, A.V. The method of ion-plasma precision nitriding of the surfaces of metal products, Patent 2555692, Russian Federation, C23C8/36 (H01J 37/00), C23C14/48, stated 27.12.2014; publ. 10.07.2015, Bull. No. 19, 13 p.

4. Mohylnaia E. P., Dubasov V. M. Yonnoe azotyrovanye yzdelyi yz konstruktsyon-noi staly $38 \mathrm{KhMFA}$. Resursozberihaiuchi tekhnolohii vyrobnytstva ta obrobky tyskom materialiv u mashynobuduvanni. 2013. №1. S. 193-198.

5. Kostyk K. O. Kostyk V. O. Porivnialnyi analiz vplyvu hazovoho ta ionno-plazmovoho azotuvannia na zminu struktury i vlastyvosti lehovanoi stali 30Kh3VA. Visnyk Nats. tekhn. un-tu «KhPI»: zb. nauk. pr. Temat. vyp. : Novi rishennia v suchasnykh tekhnolohiiakh. Kharkiv : NTU «KhPI». 2014. №48 (1090). S. 21-41.

6. Gromakovskij D. G. Sistema ponjatij i struktura modelej iznashivanija. Trenie i iznos. 1997. Tom 18. №1. S. 53-62.

7. Osipov, K. A. Nekotorye aktiviruemye processy v metallah i splavah. M. : AN SSSR, 1962. $131 \mathrm{~s}$.

8. Shvedkov E. L., Rovinskij D. Ja., Zozulja V. D., Braun Je. D. Slovar'-spravochnik po treniju, iznosu i smazke detalej mashin: Spravochnik. Kiev : Naukova dumka, 1979. 188 s. 
9. Kragel'skij I. V. Dobychin M. N., Kombalov V. S. Osnovy raschetov na trenie i iznos. M. : Mashinostroenie, 1977. $526 \mathrm{~s}$.

10. Challen, J.M., Kopalinsky, E.M. and Oxley, P.L.B. An asperity deformation model for relating the coefficient of friction and wear in sliding metal friction, in Tribology - Friction, Lubrication and Wear fifty years on, Vol II, I MechE., London (1987) Paper C156/87.

11. Terent'ev V. F., Petuhov A. N. Ustalost' vysokoprochnyh metallicheskih mate-rialov. M.: Mashinostroenie, 1981. $240 \mathrm{~s}$.

12. Dowson D. Progress in Tribology: a Historical Perspective. Plenary Papers of The World Tribology Congress. Bookcraft Limited. Bath. UK. 1997. 300. P. 3-20.

13. Gromakovsky D. G., Malyarov A. N., Samarin Y. P. Modelling and Wear Calculation on Friction. Absrtacts of Papers of the World Tribology Congress. Bookcraft Limited. Bath. UK. 1997. 462 p.

14. Eleod A. Numerical modelling of particle detachment. Absrtacts of Papers of The World Tribology Congress. Bookcraft Limited. Bath. UK. 1997. P. 44.

15. Fedorov V. V. Kinetika povrezhdaemosti i razrushenija tverdyh tel. Tashkent : FAN, 1985. $168 \mathrm{~s}$

16. Stadnychenko V. M., Dzhus R. M., Pleshkunov S. A. Metodyka pryskorenoi otsinky pokaznykiv vtomnoi poshkodzhuvanosti konstruktsiinykh materialiv. Systemy ozbroiennia i viiskova tekhnika. 2019. № 2 (58). S. 122-131. https://doi.org/10.30748/soivt.2019.58.15.

17. Stadnychenko V. M., Stadnychenko M. H., Dzhus R. M., Troshyn O. M. Pro hranytsi zastosuvannia metodu akustychnoi emisii pry vyrishenni zadach trybo diahnostyky. Zbirnyk naukovykh prats KhI VPS. 2004. №1 (10). S. 187194.

18. Dzhus R.M., Stadnychenko M. H., Popov V. V., Pleshkunov S. A., Semenov Ya. I. Po-rivnialna otsinka tekhnolohichnykh metodiv tsementatsii ta ionno-plazmovoho azotuvannia pry yikh vykorystanni dlia zmitsnennia vysokonavantazhenykh vuzliv aviatsiinoi tekhniky. Nauka i tekhnika Povitrianykh Syl Zbroinykh Syl Ukrainy. 2020. № 2 (39). S. 54-61. https://doi.org/10.30748/nitps.2020.39.06.

19. Dzhus R. M., Stadnychenko M. H., Stadnychenko V. M., Popov V. V., Pleshkunov S. A., Mikrostrukturni ta fazovi osoblyvosti poverkhnevoho sharu, zmitsnenoho ionnoplazmovym azotuvanniam, yak faktor pidvyshchennia vtomnoi mitsnosti. Zbirnyk naukovykh prats Kharkivskoho natsionalnoho universytetu Povitrianykh Syl. 2020. № 1 (63). S. 8995. https://doi.org/10.30748/zhups.2020.63.12.

20. Zaporozhets V. V., Stadnichenko V. M. Automated Systems for Tribodiagnostics of Contact Interactions. Journal of Friction and Wear. 2015. Vol. 36. № 3. P. 241-248.

21. Wang Zh., Wu X., Liu X., Cao Y., Xie J. Research on feature extraction algorithm of rolling bearing fatigue evolution stage based on acoustic emission. Mechanical Systems and Signal Processing. Vol. 113. 2018. P. 271-284.

22. Sause M., Hamstad M. Acoustic Emission Analysis. Comprehensive Composite Materials II. Vol. 7. 2018. P. 291-326. 